\title{
Hepatitis G Virus associated aplastic anemia: A recent case from Pakistan
}

\author{
Shahida Amjad Riaz Shah ${ }^{1}$, Muhammad Idrees ${ }^{2 *}$, Abrar Hussain ${ }^{2}$
}

\begin{abstract}
Background: Aplastic anemia (AA) is a serious and rare disorder characterized by a hypocellular bone marrow. Hepatitis associated aplastic anemia (HAAA) is a variant of aplastic anemia in which aplastic anemia follows an acute attack of hepatitis. Several reports have noted an association between HGV and hepatitis-associated aplastic anemia besides other hepatitis causing viruses.

Case presentation: A female girl of age 11 year with a history of loose motion for one month, vomiting for last 15 days and poor oral intake for last few days is reported here. The physical examination presents fever, pallor whereas bleeding, hepatomegaly, Splenomegaly and bruising were absent, abdominal ultrasonography confirmed the absence of hepatomegaly, Splenomegaly and lymphodenopathy. The laboratory investigation parameters were: haemoglobin $6.2 \mathrm{~g} / \mathrm{L}$, total leucocytes count 1.51 , neutrophils $0.47 \%$, absolute reticulocyte count $0.5 \%$, Monocytes 0.16\%, red cell count 3.2 mil/uL, Picked cell volume (PCV) 30.13\%, Mean Corpuscular Volume (MCV) 78 fL, Mean Corpuscular Hemoglobin (MCH) 26.3 pg. The liver enzymes were alanine aminotransferease (ALT) 98 IU/L, aspartate aminotransferase (AST) $114 \mathrm{IU} / \mathrm{L}$. Serologic and molecular tests for hepatitis A, B, C, D, E, TTV, B19 were negative, whereas HGV RNA PCR test was found positive for hepatitis $G$ virus. The bone marrow aspirate and trephine biopsy examination revealed hypo- cellularity, erythropoiesis, myelopoiesis and megakaryopoiesis.

Conclusion: HAAA is an uncommon but severe condition, which may occur following idiopathic cases of acute hepatitis. Our finding suggests the involvement of HGV in the development of aplastic anemia. In patients presenting with pancytopenia after an episode of acute hepatitis, the definitive diagnosis should be considered and confirmed by RT-PCR and if possible by bone marrow biopsy.
\end{abstract}

\section{Introduction}

Hepatitis $\mathrm{G}$ virus was reported first time has a non-A-E hepatitis and placed as flavivirus [1].The induction of this new agent in the family of Hepatitis has attracted significant attention because of its etiology [2]. Hepatitis G virus has been marked as a cause of non-A through $E$ acute viral hepatitis and sharp liver failure. Aplastic anemia complicating hepatitis is an uncommon but well recognized phenomenon. Hepatitis associated aplastic anemia is a severe disorder with a high mortality (85\%) [3].Hepatitis associated aplastic anemia (HAAA) is a deviation of aplastic anemia in which aplastic anemia follows an acute attack of hepatitis. The marrow failure can be severe and is

\footnotetext{
* Correspondence: idreeskhan96@yahoo.com

${ }^{2}$ Division of Molecular Virology, National Centre of Excellence in Molecular Biology, 87-West Canal Bank Road Thokar Niaz Baig Lahore-53700, University of the Punjab Lahore, Pakistan

Full list of author information is available at the end of the article
}

usually lethal if untreated. Lorenz and Quazier has documented first time HAAA in two case back in 1955 [4], by 1975 more than 193 cases had been reported [5]. Adil et al has reported, severe aplastic anaemia (SAA) $51.4 \%$, very severe (VSAA) in $16.7 \%$ of 144 patients of aplastic anemia cases [6]. A number of reports have mentioned alliance between HGV and HAAA [7-10]. Number of HAAA cases with a history of multiple blood transfusions has been reported [11,12]. Crespo et al has documented a case of 24 year old man have community acquired HGV that later progress into severe aplastic anemia, point out HGV for both hepatitis and aplastic anaemia. However greater number of serum samples are needed to prove the association of hepatitis G virus and aplastic anaemia [13]. Moatter et al. has reported $5 / 43$ patients of haemodialysis with raised liver enzyme, reduced platelet count and 21/100 patients of polytransfused $b$ - thalassemia major children infected with HGV RNA form Pakistan [14,15].

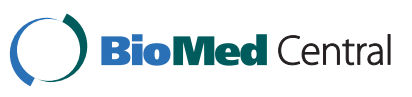

() 2011 Riaz Shah et al; licensee BioMed Central Ltd. This is an Open Access article distributed under the terms of the Creative Commons Attribution License (http://creativecommons.org/licenses/by/2.0), which permits unrestricted use, distribution, and reproduction in any medium, provided the original work is properly cited. 


\section{Case Presentation}

In this study well characterized samples of 93 aplastic anaemia patients before blood tranfusion were included. These characteristics include history, physical examination, haematological investigation, bone marrow aspirate and trephine biopsy examination, liver function test (LFTs), renal parameters, viral profile and abdominal ultrasonography. The diagnosis of HA-aplastic anemia was made on the basis of hepatitis (elevated serum aminotransferase enzymes, jaundice, absolute neutrophils counts, platelet counts and reticulocytes. All the 93 samples were checked for serological marker of HAV, HBV, HCV, HDV, HEV, HGV,TTV and B19. One of 93 samples from patients with HA-aplastic anemia has hepatitis G associated aplastic anaemia with positive HGV RNA.

A female girl of age 11 year is reported here. The patient had a history of loose motion for one month, vomiting for last 15 days and poor oral intake for last few days. The physical examination presents fever, pallor whereas bleeding, hepatomegaly, Splenomegaly and bruising were absent, abdominal ultrasonography confirmed the absence of hepatomegaly, Splenomegaly and lymphodenopathy. The laboratory investigation parameters were: haemoglobin $6.2 \mathrm{~g} / \mathrm{L}$, total leucocytes count 1.51 , neutrophils $0.47 \%$, absolute reticulocyte count $0.5 \%$, Monocytes $0.16 \%$, red cell count $3.2 \mathrm{mil} / \mathrm{uL}$, Picked cell volume (PCV) 30.13\%, Mean Corpuscular Volume (MCV) 78 fL, Mean Corpuscular Hemoglobin $(\mathrm{MCH}) 26.3 \mathrm{pg}$. The liver enzymes were alanine aminotransferease (ALT) $98 \mathrm{IU} / \mathrm{L}$, aspartate aminotransferase (AST) 114 IU/L. Serologic and molecular tests for hepatitis A, B, C, D, E, TTV, B19 were negative, whereas HGV RNA PCR test was found positive for hepatitis G virus. The bone marrow aspirate and trephine biopsy examination revealed hypo- cellularity, erythropoiesis, myelopoiesis and megakaryopoiesis.

\section{Discussion}

Flaviviruses belong to enveloped viruses with a single positive sence RNA about $10 \mathrm{~kb}$. Hepatitis G virus medium of transmission mostly through blood. The possible roel of hepatitis $G$ virus infection in the pathogenesis of rare non-liver disease has been suggested but need to be recognized. By some unknow reseason aplastic anemia some time proceded by hepatitis. Few reports have analysed the role of HGV in the development of HAAA $[8,9,11]$. Crespo et al in print a case through negative serological markes for HAV, HBV, HCV, HEV, hypoplastic marrow low platelet and white cell counts but detected HGV-RNA before any blood transfusion [13]. Byrnes et al has described hepatit G Virus positive case of 26 year old man before the use of medication, blood tranfusion or intravenous drug abuse [9]. Zaidi et al, reported a 19 year male before blood transfusion with positive HGV by RT-PCR and suggested that in the absence of any other clincial manifestions the possible infectious agent may be HGV for hepatitis G virus associated aplast anaemia [8]. In the list of studies of Hepatitis G Virus associated aplastic anaemia before blood transfusion we report a case of 11 years female girls.

Whereas some reports confirms the presence of HGV viraemia in the patient aplastic anaemia after blood transufion [8,9,11,12,16-18]. But however concluded that HGV viraemia is frequent in patients with aplastic anaemia [19]. Kiem et al reported similar finding after logistic regression analysis, that HGV RNA in transfused patients was 5.9 times higher compare to untransfused patients $(\mathrm{P}=0.001)$. This implicates transfusion as major source of HGV with aplastic anaemia [18].

The published literature point out that studies must be performed on many more aplastic anaemia patients prior to blood transfusion [20]. However, to find such patients in large number are not normally avaible to study, so far individual cases are reported. The ideal case regarding Hepatitis $G$ associated aplastic anaemia are pre blood transfusion.

\section{Conclusion}

In conclusion, HAAA is an uncommon but severe condition, which may occur following idiopathic cases of acute hepatitis. Our finding suggests the involvement of HGV in the development of aplastic anemia. In patients presenting with pancytopenia after an episode of acute hepatitis, the definitive diagnosis should be considered and confirmed by RT-PCR and if possible by bone marrow biopsy.

\section{Consent}

Written informed consent was obtained from the patients a copy of which is available for review by Editor-in-Chief of this journal.

\section{Author details \\ ${ }^{1}$ Hematology Department, Sheikh Zayed Medical Complex, Lahore Pakistan. ${ }^{2}$ Division of Molecular Virology, National Centre of Excellence in Molecular Biology, 87-West Canal Bank Road Thokar Niaz Baig Lahore-53700, University of the Punjab Lahore, Pakistan. \\ Authors' contributions \\ SARS aided in acquistion of data that was included in this case report and drafted the manuscript. MI aided in acwuision and interpretation of the data analysed. AH helped in statistical analysis of the data and in editing of this manuscript. All authors have read and approved the final version of this manuscript.}

\section{Authors Information}

SARS: Consultant Hematologist, Sheikh Zayed Medical Complex. MI: Consultant Molecular Virologist, Ministry of Education. AH: Assistant Professor and PhD Research Scholar. 


\section{Competing interests}

The authors declare that they have no competing interests.

Received: 29 December 2010 Accepted: 21 January 2011

Published: 21 January 2011

\section{References}

1. Simons JN, Pilot-Matias TJ, Leary TP, Dawson GJ, Desai SM, Schlauder GG, et al: Identification of two flavivirus-like genomes in the GB hepatitis agent. Proc Natl Acad Sci USA 1995, 92(8):3401-5.

2. Reshetnyak VI, Karlovich TI, Ilchenko LU: Hepatitis G virus. World J Gastroenterol 2008, 14(30):4725-34.

3. Fatemeh Farahmand GHF, Touran Shahraki, Gholam Reza Khatami, Mina Izadiar GAR: Hepatitis-Associated Aplastic Anemia. Govaresh 2005, 10(1):54-8.

4. Lorenz EQK: Panmyelopathy following epidemic hepatitis. Wien Med Wochenschr 1955, 8(105(1)):19-22.

5. Hagler L, Pastore RA, Bergin JJ, Wrensch MR: Aplastic anemia following viral hepatitis: report of two fatal cases and literature review. Medicine, Baltimore 1975, 54(2):139-64.

6. Adil SN, Burney IA, Kakepoto GN, Khurshid M: Epidemiological features of aplastic anaemia in Pakistan. J Pak Med Assoc 2001, 51(12):443-5.

7. Hibbs JR, Frickhofen N, Rosenfeld SJ, Feinstone SM, Kojima S, Bacigalupo A, et al: Aplastic anemia and viral hepatitis. Non-A, Non-B, Non-C? JAMA 1992, 267(15):2051-4.

8. Zaidi Y, Chapman CS, Myint S: Aplastic anaemia after HGV infection. Lancet 1996, 348(9025):471-2.

9. Byrnes JJ, Banks AT, Piatack M Jr, Kim JP: Hepatitis G-associated aplastic anaemia. Lancet 1996, 348(9025):472.

10. Linnen J, Wages J Jr, Zhang-Keck ZY, Fry KE, Krawczynski KZ, Alter H, et al: Molecular cloning and disease association of hepatitis $G$ virus: a transfusion-transmissible agent. Science 1996, 271(5248):505-8.

11. Brown KE, Tisdale J, Barrett AJ, Dunbar CE, Young NS: Hepatitis-associated aplastic anemia. N Engl J Med 1997, 336(15):1059-64.

12. Kiem HP, Storb R, McDonald GB: Hepatitis-associated aplastic anemia. N Engl J Med 1997, 337(6):424-5.

13. Crespo JdIHB, Rivero M, Lozano JL, Fábrega E, Pons-Romero F: Hepatitis $G$ virus infection as a possible causative agent of community-acquired hepatitis and associated aplastic anaemia. Postgrad Med J 1999, 881(75):159-60.

14. Moatter T, Tariq SA, Fisher-Hoch S, Haroon S, McCormick JB: Hepatitis G virus in Karachi, Pakistan. Lancet 1996, 348(9037):1318-9.

15. Moatter T, Adil S, Haroon S, Azeemuddin S, Hassan F, Khurshid M: Prevalence of hepatitis $\mathrm{G}$ virus in Pakistani children with transfusion dependent beta- thalassemia major. Indian J Pathol Microbiol 1999, 42(4):475-82.

16. Kiem HP, Myerson D, Storb R, McDonald GB, Spurgeon CL, Leisenring W: Prevalence of hepatitis $\mathrm{G}$ virus in patients with aplastic anemia. Blood 1997, 90(3):1335-6

17. Alter HJ, Nakatsuji Y, Melpolder J, Wages J, Wesley R, Shih JW, et al: The incidence of transfusion-associated hepatitis $\mathrm{G}$ virus infection and its relation to liver disease. N Engl J Med 1997, 336(11):747-54.

18. Moriyama $K$, Okamura T, Nakano S: Hepatitis GB virus $C$ genome in the serum of aplastic anaemia patients receiving frequent blood transfusions. Br J Haematol 1997, 96(4):864-7.

19. Brown KE, Wong S, Young NS: Prevalence of GBV-C/HGV, a novel 'hepatitis' virus, in patients with aplastic anaemia. Br J Haematol 1997, 97(2):492-6.

20. Robaczewska M, Cova L, Podhajska AJ, Falkiewicz B: Hepatitis G virus: molecular organization, methods of detection, prevalence, and disease association. Int J Infect Dis 1999, 3(4):220-33.

doi:10.1186/1743-422X-8-30

Cite this article as: Riaz Shah et al:: Hepatitis G Virus associated aplastic anemia: A recent case from Pakistan. Virology Journal 2011 8:30.

\section{Submit your next manuscript to BioMed Central and take full advantage of:}

- Convenient online submission

- Thorough peer review

- No space constraints or color figure charges

- Immediate publication on acceptance

- Inclusion in PubMed, CAS, Scopus and Google Scholar

- Research which is freely available for redistribution

Submit your manuscript at www.biomedcentral.com/submit 